\title{
The Mental Health Nursing Review: implications for community psychiatric nurses
}

\author{
Kevin Goumay"
}

\begin{abstract}
The recent reviow of mental hecilh mursing recommended that nurses relocus thetr attention on people with sertous mental tiness. There ore some encouracing trends in tho training of nurses in problemortented case mancoement. However, montal hectth muring needs to foce verious problems. These inchude the need for the loros-sceds rotroining of mures currently working in trocitional poychiotitic hosplits and cinficutties in the now Project 2000 programmes. In oddition, there is a clocer lock of loadership in the

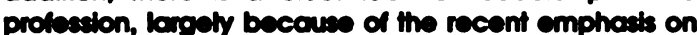
manogement rather than clinical and ocademic aftributes. Fincily, mursing needs people who care what hoppens to the sertounty mentally it.
\end{abstract}

The recent review of mental health nursing published in April 1994, contained over 40 recommendations (Department of Health, 1994). The most important of these was that there should be a refocus by mental health nurses on people with serious mental illness. This will hopefully correct the scandalous situation reported by White (1991) in the results of his Quinquennial Survey of Community Psychiatric Nurses (CPNs). This survey, which collected data on virtually all CPN services throughout the United Kingdom, showed that at the time of the survey in 1990 only $27.2 \%$ of clients on CPN caseloads had a principal diagnosis of schizophrenia, and a quarter of CPNs had no people with schizophrenia at all on their caseloads. Further to this, the Mental Health Nursing Review estimated that $80 \%$ of people with schizophrenia who were

-Professor Kevin Gournay, was a co-opted member of the Review of Mental Health Nursing. is currently a member of the Clinical Standards Advisory Group Schizophrenia Committee and is an elected new affliate of the Royal College of Psychiatrists. living in the community had no attached CPN. White's survey also revealed that CPNs were increasingly detaching themselves from consultant psychiatrists and multidisciplinary teams and the picture reported was that referrals from GPs to CPNs were increasing, whereas referrals from consultant psychiatrists were decreasing. As a corollary to this, CPNs were increasingly working with anxiety and depression in primary health care, using counselling as their central approach. A recent study (Gournay \& Brooking 1994) has revealed that CPNs' endeavours in this area have very poor clinical outcomes and that the cost to the health care system of this work is enormous compared with the cost of work with people with serious mental illness (Gournay \& Brookdng, 1994 ${ }^{\mathrm{b}}$. Thus, the Review Steering Committee, which comprised not only mental health nurses but also representatives from all other key professions and a range of user groups, was able to make the very strong and central recommendation about the refocus on serious mental illness.

\section{Implications for CPNs}

One other recommendation was that the title 'mental health nurse' should be used for all nurses, whether they work in hospitals or in the community, reflecting a flexible role for nurses within the services of the future which hopefully will provide seamless care. However. although there are many positive signs that mental health nursing may be able to meet the challenge posed by the seriously mentally ill. there are also considerable problems to be faced.

Turning to the more positive aspects, there are several initiattves in the area of retraining for mental health nurses. Arguably the most 
important of these initiatives is the Thorn Programme which is funded by the Sir Jules Thorn Trust and based at the Institute of Psychiatry and at the University of Manchester. This initiative has been the subject of considerable involvement by members of the Royal College of Psychiatrists. The programme, which is run on a part-time basis, trains nurses in problemoriented case management, giving them skills in brokering, networking, and assertive outreach as well as in psychoeducational initiatives with families and cognittve behavioural interventions with posittve and negative symptoms. This programme will be producing dozens of graduates over the next few months who should be very well equipped to act as highly skilled case managers. This development is mirrored by other initiatives such as the Sainsbury Centre Training Initiative in Case Management and a skillsoriented Masters programme which I run at Middlesex Untversity. Such innovations will also hopefully be informed by the work of the Clinical Standards Advisory Group on Schizophrenia which is currently developing a picture of services throughout the country and will identify not only care and treatment standards but also training needs. It is hoped that this work will lead to the more specific targeting of training for mental health nurses. However, more negatively and in contrast to these promising signs, one needs to consider the very much larger numbers of mental health nurses who currently work in traditional psychiatric hospitals who will desperately require retraining when their hospitals are finally closed, but for whom such resources are unlikely to be available in the future.

Again, on a negative note, mental health nursing is encumbered by the new Project 2000 training, which has eschewed the old apprenticeship model for a university based training. This new system of training has come under considerable attack from many quarters and some disturbing evidence (White \& Riley. 1993) shows that mental health nurses from this programme are poorly prepared for clinical practice. This finding seemed inevitable given that students spend 18 months in a Common Foundation Programme studying theory, much of which is arguably of little importance, then spend 18 months training in a mental health branch, with a very small (by comparison with the old registered mental nurse programme) amount of clinical practice. Preregistration training is also encumbered by the continuing emphasis on sociological theories, the rejection of the 'medical model' and the continuing preponderance of anti-psychiatric theories on the curriculum. These Project 2000 courses are generally taught by nurse tutors and lecturers who have had very little clinical experience in the recent past. Indeed, the Mental Health Nursing Review recognised this phenomenon and recommended that tutors and lecturers spend at least one day in a clinical environment. This is, however, probably less than adequate as many of these tutors and lecturers have never been exposed to the key contemporary developments such as case management or cognitive behavioural approaches. Furthermore, nurse training has, for many years now, rejected any significant medical input and many Project 2000 courses will run from beginning to end without students ever having any teaching contact with psychiatrists. This omission is largely the responsibility of anti-psychiatry obsessed tutors and lecturers who continually emphasise a malevolent medical model to their students. These same lecturers have also carefully engineered the removal of traditional psychiatry from significant parts of the curriculum.

\section{Conclusion}

The Mental Health Nursing Review looked in detail at the apparent lack of leadership in the nursing profession and made recommendations which will hopefully lead to potential leaders of the profession being identified and nurtured accordingly. The concern of the review group was perhaps generated by the situation whereby success in the contemporary mental health nursing arena is now generally judged by how far one is promoted up the management ladder rather than on clinical expertise. Surely, the services of the future need mental health nurse leaders who are not managers but practitioners and teachers. In addition these people need to have knowledge and skills based on contemporary research based practice and, overall, they need a passion for ameliorating the distress of people with serious mental illness.

\section{References}

DEPARTMENT OF HEALTH (1994) Working in Partnership. London: HMSO

Gournay, K. J. M. \& Brooking, J. I. (1994") Community psychiatric nurses in primary health care. Brttish Journal of Psychiatry. 165, 231-238. 
- \& - (1994) The community psychiatric nurse in primary care: an economic analysis. In Community Psychlatric Nursing. Vol. II. C. Brooker, \& E. White, London: Chapman \& Hall.

WHrTe, E. (1991) The Thind Qutnquennial National Community Psychiatric Nursting Survey. Untversity of Manchester: Department of Nursing Monograph.

- \& RHEY, E. (1993) A Detalled Study of the Relationship between Teaching. Support and Role Modelling for Students in Clinical Areas within the Context of
Project 2000 Courses. Royal College of Nursing. Research Advisory Group Conference: University of Glasgow.

Kevin Gournay, Professor of Mental Health. Faculty of Social Science and Education, Middlesex University, Enfield, Middlesex EN3 4SF

\title{
The relationship between a community psychiatric rehabilitation feam and local GPs
}

\author{
Sandra Tough
}

\begin{abstract}
As menial health profestionals move increasingly towards providing community-based senvices, a good working relationship with general practitionors becomes central to patient care. This relationship depends on good llotson and communication as well as shared ooats. This study examines the relationship between a community poychiaticic rehablitiation toam (CPR) and GPs by means of a poetal questionncire to local pincipals in general proctice. Although the awareness of the service was less than optimum, clear indications were made of ways of improving communication. The EPs ovenwholningty supported the priortlles of the CPRT in the care of those with major mental lilness.
\end{abstract}

Over the past 30 years the role of the psychiatric hospital in the care of those with long-standing mental health problems has declined, to be replaced by systems of community care (Thornicroft \& Bebbington, 1989). This has not only involved establishing alternative residential facilities but has also required provision for a range of support needs for people with multiple disabilities and disadvantages.

As psychiatrists and psychiatric nurses move increasingly into the local community, they may find their roles and responsibilities overlapping with other community based professionals, in particular general practitioners (Kendrick et al, 1991). There is therefore a need for community based psychiatric services to ensure good liaison and communication with other professionals as well as the development of shared aims and understanding (Bennet, 1989). The clinical role of the GP in providing primary medical care for the long-term mentally 111 has been recognised (House of Commons Social Services Committee, 1985). They are the most consistent point of contact with the caring professions for people who frequently drift in and out of psychiatric care.

This paper examines the relationship between a community-based psychiatric rehabilitation team and local GPs. 